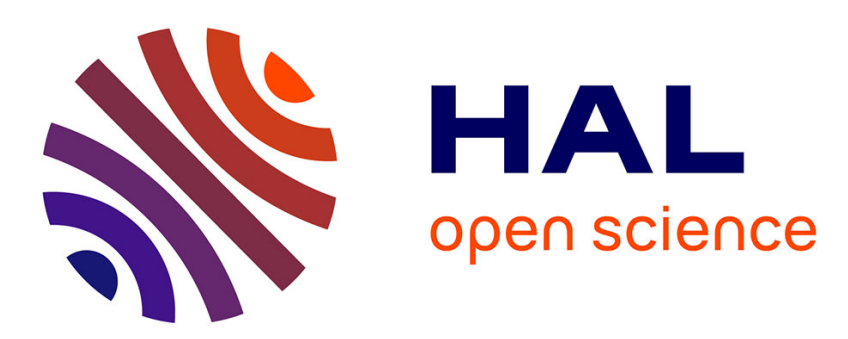

\title{
A case of trisomy 28 in cattle revealed by both banding and FISH-mapping techniques
}

L. Iannuzzi, G.P. Di Meo, P.S. Leifsson, Andre A. Eggen, K. Christensen

\section{To cite this version:}

L. Iannuzzi, G.P. Di Meo, P.S. Leifsson, Andre A. Eggen, K. Christensen. A case of trisomy 28 in cattle revealed by both banding and FISH-mapping techniques. Hereditas, 2001, 134, pp.147-151. 10.1111/j.1601-5223.2001.00147.x . hal-02682238

\section{HAL Id: hal-02682238 \\ https://hal.inrae.fr/hal-02682238}

Submitted on 1 Jun 2020

HAL is a multi-disciplinary open access archive for the deposit and dissemination of scientific research documents, whether they are published or not. The documents may come from teaching and research institutions in France or abroad, or from public or private research centers.
L'archive ouverte pluridisciplinaire HAL, est destinée au dépôt et à la diffusion de documents scientifiques de niveau recherche, publiés ou non, émanant des établissements d'enseignement et de recherche français ou étrangers, des laboratoires publics ou privés. 


\title{
A case of trisomy 28 in cattle revealed by both banding and FISH-mapping techniques
}

\author{
LEOPOLDO IANNUZZI' ${ }^{1}$, GIULIA PIA DI MEO ${ }^{1}$, PẢLL S. LEIFSSON ${ }^{2}$, ANDRÉ EGGEN ${ }^{3}$ and \\ KNUT CHRISTENSEN ${ }^{4}$ \\ ' National Research Council (CNR), IABBAM, Laboratory of Animal Cytogenetics, Naples, Italy \\ ${ }^{2}$ Dept. of Pharmacology and Pathobiology, Royal Veterinary and Agricultural University, Frederiksberg, \\ Denmark \\ ${ }^{3}$ Laboratoire de Génétique biochimique et de Cytogénétique, Department of Animal Genetics, Jouy-en-Josas, \\ France \\ ${ }^{4}$ Division of Animal Genetics, Department of Animal Science and Animal Health, Frederiksberg, Denmark
}

\begin{abstract}
Iannuzzi, L., Di Meo, G. P., Leifsson, P. S., Eggen, A. and Christensen, K. 2001. A case of trisomy 28 in cattle revealed by both banding and FISH-mapping techniques.-Hereditas 134: 147-151. Lund, Sweden. ISSN 0018-0661. Received April 9, 2001. Accepted July 18, 2001

A case of presumed trisomy 22 in cattle, as earlier reported, was investigated by using both chromosome banding and FISH-mapping techniques. A one year old Hereford female calf showed slow growth, brachygnathia superior, hyper-salivation, strabisbusmus convergence, macroclitoris and supernumerary nipples. At necropsy, a duplication of the uterine cervix and an extra aortic cusp were also observed. The R-banding technique revealed that BTA28 (not BTA22, as erroneously earlier reported) was involved in the trisomy. This was confirmed by FISH-mapping with chromosome-specific markers. Phenotypic characteristics achieved in cattle carrier and those earlier reported in humans carrying partial trisomy 10 were discussed.
\end{abstract}

L. Iannuzzi, CNR-IABBAM, Via Argine 1085,80147 Naples-Ponticelli,Italy. E-mail: L.Iannuzzi@iabbam.na.cnr.it

Identification of cattle autosomes (BTA) is often difficult for their acrocentric nature, especially when poor banding techniques and contracted chromosome preparations are used. Since the cases of trisomy in cattle are very rare (reviewed by CHRISTENSEN and JUUL 1999), the identification of chromosomes involved in the anomalies is very important, especially in abnormal phenotypes for the possibility to correlate animal and human pathologies involving homologous chromosomes or chromosome regions. Indeed, both Zoo-FISH analyses (reviewed by IANNUZZI et al. 1999) and comparative FISH-mapping (SCHIBLER et al. 1998; IANNUZZI et al. 2000) between human and bovid chromosomes revealed that numerous human segments have been conserved in bovid genomes.

The case reported here is the same earlier studied by CHRISTENSEN and JUul (1999) who classified this trisomy as BTA22. It is difficult to establish if other cases reported also as trisomy of BTA22 (MAYR et al. 1985, Sakai et al. 1991; Agerholm and ChrisTENSEN 1993) involved the same chromosome or not, because of poor banding techniques applied for chromosome identification.

Since specific type I molecular markers have been assigned to each cattle chromosome (TEXAS NOMENClAture 1996; Gautier et al. 2001) and new Q-, Gand R-banded karyotypes have recently been ar- ranged (ISCNDB2000 2001) using the Texas system (1996) as point of reference, the use of specific markers may be very useful in clinical cytogenetics.

In the present study more effective chromosome R-banding patters and the use of specific type I molecular markers allow a definitive identification of the chromosome involved in the presumed trisomy 22.

\section{MATERIALS AND METHODS}

A one year old Hereford female earlier investigated by CHRISTENSEN and JuUl (1999) underwent cytogenetic investigations. Drops of cell suspension obtained from BrdU-treated blood cell cultures (CHRISTENSEN and JuUl 1999) kept frozen until now, were spread on slides which were used for both RBG-banding (R-bands by late incorporation of 5Bromodeoxyuridine and Giemsa staining) and fluorescence in situ hybridization (FISH) techniques. As probes, the bovine BAC-clones mapping LTF (lactotransferrin, marker of BTA22) and CGN1 (conglutinin 1, marker of BTA28) (TEXAs NOMENClATURE 1996; ISCNDB2000 2001; GAUTIER et al. 2001) were used. Slide-treatment for FISH-technique, in situ hybridization, signal detection, image capturing by CCD-camera, image processing and printing were as recently reported (IANNUZZI et al. 2000). 

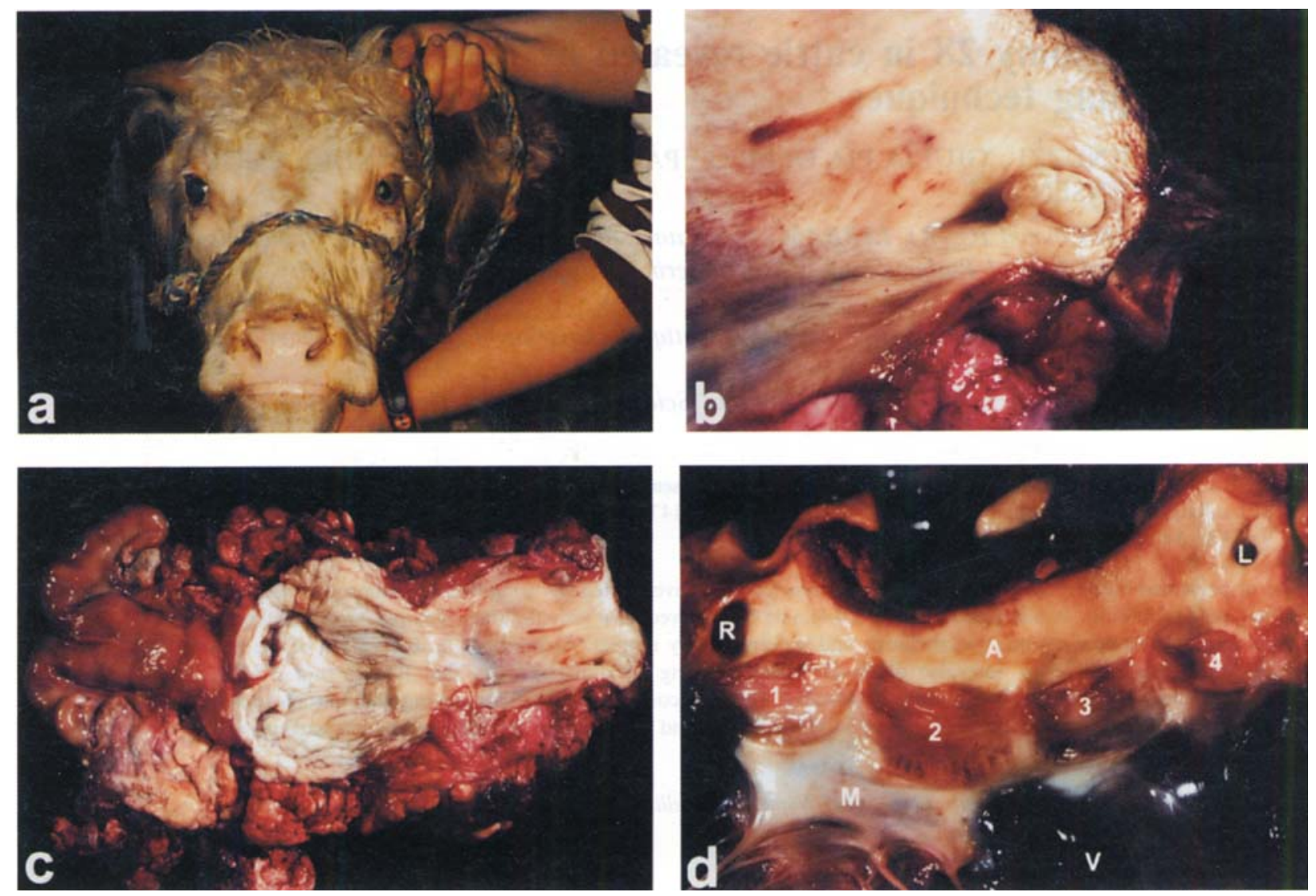

Fig. 1a-d. Particulars of the female Hereford calf carrying the trisomy 28 . Notice the brachygnathia superior $(2 \mathrm{~cm})$ and the strabismus convergence (a), the macroclitoris (b), the duplication of the uterine cervix (c), and an extra aortic cusp (d). In Fig. Id we indicated the right (R) and left (L) coronary arteries, the aorta (A), the ventricle (V), the mitral valve (M) and the four (one more) septal cups $(1-4)$.

Karyotypes and chromosome identification followed both the TEXas NOMENClature (1996) and the recent cattle standard karyotypes (ISCNDB2000 2001).

\section{RESULTS AND DISCUSSION}

Clinical observations on the female calf affected by the presumed trisomy 22 were in part reported earlier but not shown (CHRISTENSEN and JUUL 1999). In summary, the one year old Hereford female calf showed: slow growth, brachygnathia superior (Fig. 1a), hyper-salivation, strabisbusmus convergence (Fig. 1a), macroclitoris (Fig. 1b) and supernumerary nipples ( 7 in total). At necropsy, a duplication of the uterine cervix (Fig. 1c) and an extra aortic cusp (Fig. 1d) (probably due to duplication of the septal cusp) were also observed.

All fifty cells examined showed 61 chromosomes $(2 \mathrm{n}=61, \mathrm{XX})$, confirming previous results (CHRISTENSEN and JUUL 1999). However, the ten RBGbanded karyotypes performed revealed the presence of three chromosomes 28 (Fig. 2), not of BTA22, as earlier reported (CHRISTENSEN and JUUL 1999). This was confirmed by FISH analysis with BAC-clone containing CGN1 (Fig. 3a-b). A FISH-mapping control with LTF (BTA22) revealed that BTA22 is not involved in the trisomy (Fig. 3c).

According to these new results, all previous conclusions on the homologies between BTA22 and HSA3 (Christensen and Juul 1999) must be rejected. Furthermore, the heterogeneity found in the cases with presumed trisomy 22 earlier described (MAYR et al. 1985; SAKai et al. 1991; Agerholm and ChrisTENSEN 1993) suggests that different chromosomes may be involved in the cases with presumed trisomy 22.

As known, CGN1 is a marker of bovine U29 (BTA28) (Texas Nomenclature 1996; ISCNDB2000 2001). Furthermore, BTA28 (and goat chromosome 28, CHI28) is painted by HSA10 (Texas Nomenclature 1996). However, looking at BOVMAP database, GOATMAP database and GDB (human), it is evident that genes found in both BTA28 (ACTA1, HK1, PLAU, SAP2 and CGN1) and CHI28 (ACTA2, AGT, RBP3, DNTT) are lo- 


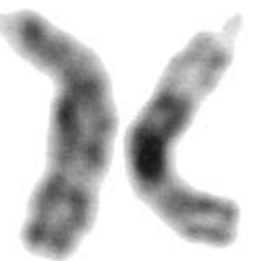

1

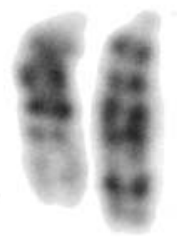

7
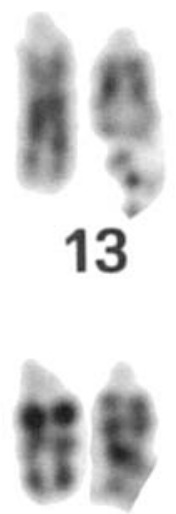

19

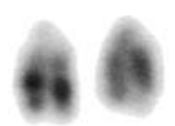

25
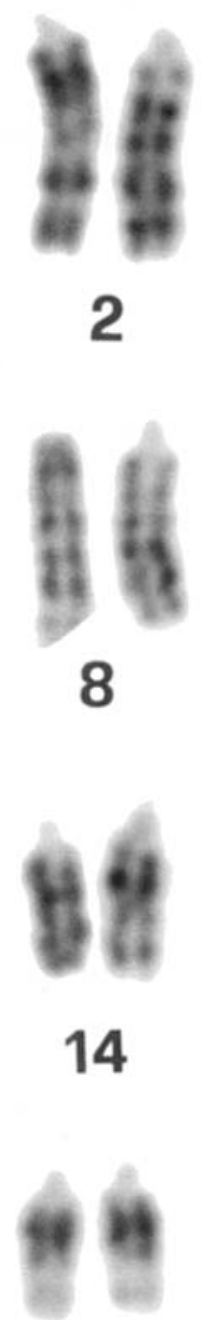

2

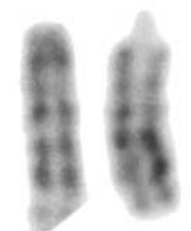

8

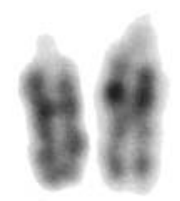

14

20

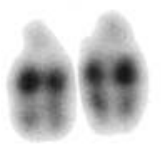

26

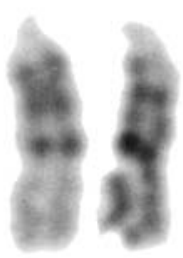

3

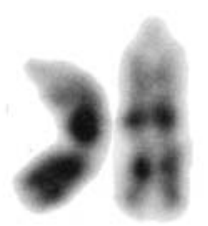

9

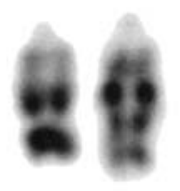

15

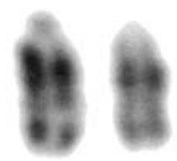

21

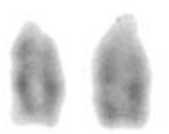

27

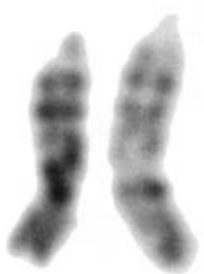

4

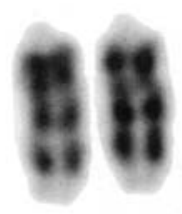

10

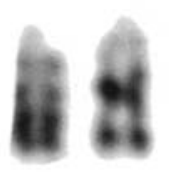

16

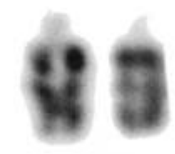

22

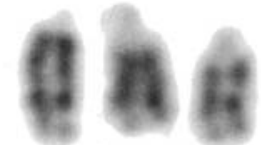

28

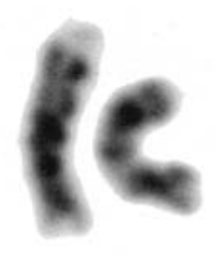

5

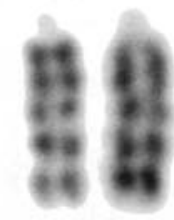

11

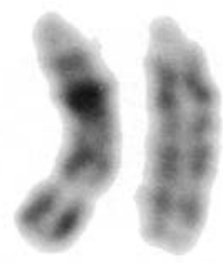

6

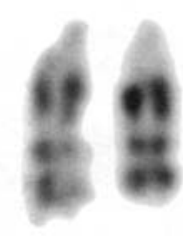

12

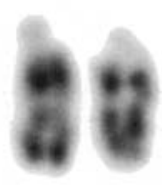

17

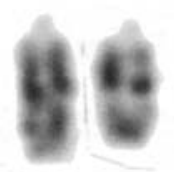

18
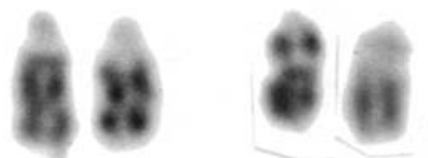

23

24

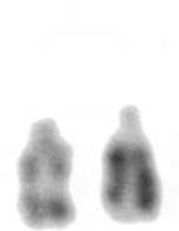

29

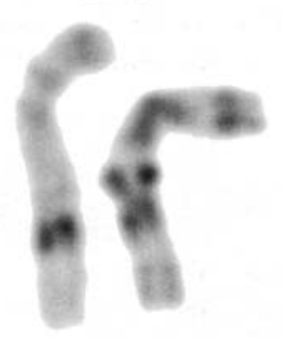

$x \times$

Fig. 2. RBG-banded karyotype $(2 n=61, X X+28)$ of female cattle carrying the trisomy 28 .

cated not only on HSA10 (HK1, PLAU, ACTA2, RBP3) but also on HSAl (AGT) and HSA2 (DNTT).

It is interesting to notice that HSA10 has been involved in partial trisomies (Boon et al. 1996; DAvies et al. 1998). Among the various features reviewed by BOON et al. (1996) in different cases with partial trisomy of HSA10, a cleft lip (with possible cleft palate), strabismus and cardiac abnormalities were observed in the carriers. These features are very similar to some of those observed in the case reported in the present study (Fig. 1).

This study underlines the necessity to use more effective banding techniques, as well as specific molecular markers, for the identification of chromosomes involved in abnormal karyotypes. This re- 

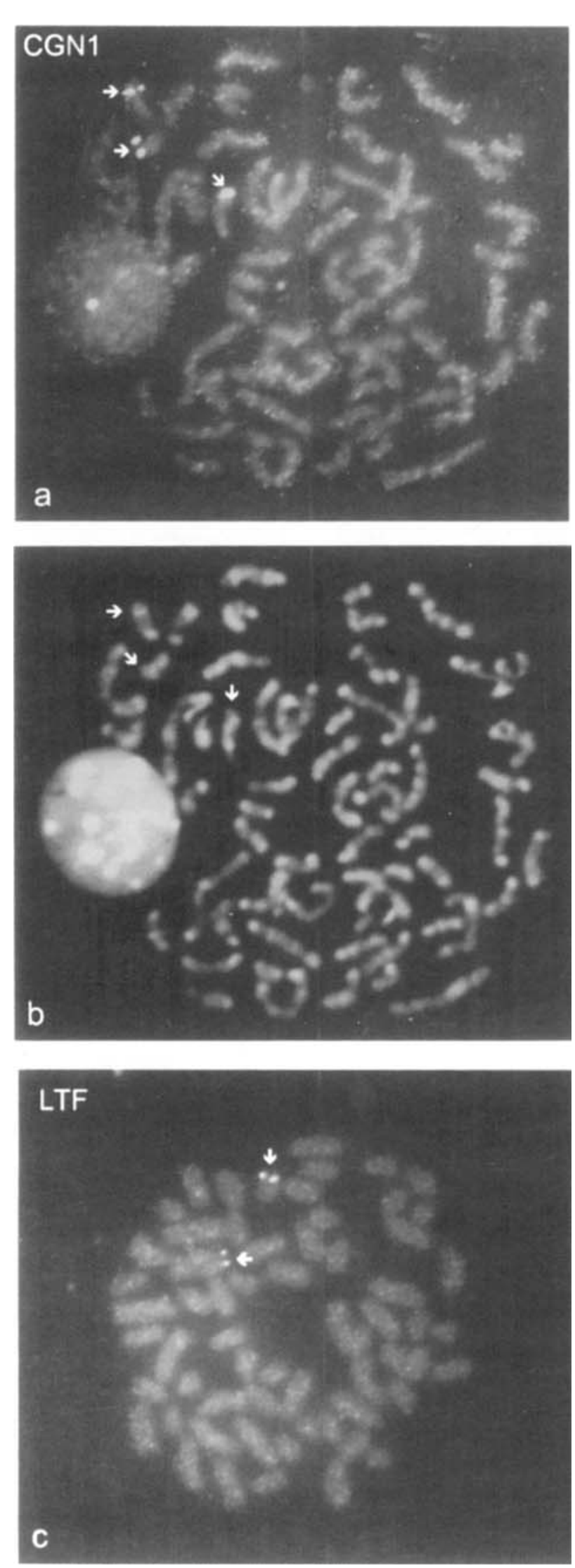

quires a good collaboration among different groups. Certainly, the clinical cytogenetics of cattle (and related species) will receive enormous benefits when cattle specific chromosome painting probes will be commercially available.

\section{ACKNOWLEDGEMENTS}

The authors wish to acknowledge the excellent technical assistance and microscope image processing of $\mathrm{Mr} \mathrm{D}$. Incarnato, from CNR-IABBAM of Naples. This study has in part been supported by National Research Council, Special Project on the Biodiversity.

\section{REFERENCES}

Agerholm JS and Christensen K, (1993). Trisomy 22 in a calf. J. Vet. Med. A 40: 576-581.

Boon C, Markello T, Jackson-Cook C and Pandya A, (1996). Partial trisomy 10 mosaicism with cutaneous manifestation: report of a case and review of the literature. Clin. Genet. 50: 417-421.

Christensen K and Juul L, (1999). A case of trisomy 22 in a live hereford calf. Acta Vet. Scand. 40: 85-88.

Davies J, Jaffe A and Bush A, (1998). Distal 10q trisomy syndrome with unusual cardiac and pulmonary abnormalities. J. Med. Genet. 35: 528-529.

Gautier M, Laurent P, Hayes H and Eggen A, (2001). Development and assignment of bovine specific PCRsystem for the Texas nomenclature marker genes and isolation of homologous BAC-probes. Genet. Sel. Evol. 33: $191-200$.

Iannuzzi L, Di Meo GP, Perucatti A and Incarnato D, (1999). Comparison of the human with the sheep genomes by use of human chromosome-specific painting probes. Mammal. Genome 10: 719-723.

Iannuzzi L, Di Meo GP, Perucatti A, Schibler L, Incarnato D, Ferrara L, Bardaro T and Cribiu EP, (2000). Sixteen type I loci from six human chromosomes were comparatively fluorescent in-situ mapped to river buffalo (Bubalus bubalis) and sheep (Ovis aries) chromosomes. Chromosome Res. 8 (5): 447-450.

ISCNDA2000, (2001). International System for Chromosome Nomenclature of Domestic Bovids. (eds. D Di Berardino, GP Di Meo, DS Gallagher, $\mathrm{H}$ Hayes and L Iannuzzi (co-ordinator)) Cytogenet. Cell Genet. 92: 283-299.

Mayr B, Krutzler H, Auer H, Schleger W, Sasshofer K and Glawisching E, (1985). A viable calf with trisomy 22. Cytogenet. Cell Genet. 39: 77-79.

Fig. 3a-c. Metaphase plates of the female cattle carrying the trisomy 28. a-b. Sequential procedure showing an early-metaphase treated for FISH-technique with the bovine BAC-clone containing CGN1 (a) and RBA-banding technique (b). Notice the clear three FITC-signals on the telomeric regions of BTA28 (arrows). A FISH-mapping control with the BAC-clone containing LTF (marker of BTA22) revealed only two FITC-signals on BTA22 (arrows) (c). 
Sakai J, Ogata Y, Takahashi K, Watanabe D, Murakami R, Miyake Y and Kaneda Y, (1991). Autosomal trisomy found in a japanese black calf with brachygnathia superior born from a dam having chromosomal translocation (in Japanese). Jap. Anim. Reprod. 37: 185-189.

Schibler L, Vaiman D, Oustry A, Giraud-Delville C and Cribiu EP, (1998). Comparative gene mapping: a fine- scale survey of chromosome rearrangements between ruminants and humans. Genome Res. 8: 901-915.

Texas Nomenclature, (1996). Standardization of cattle karyotype nomenclature: report of the committee for the standardization of the cattle karyotype (eds CP Popescu, S Long, P Riggs, J Womack, S Schmutz, R Fries and D Gallagher). Cytogenet. Cell Genet. 74: $259-261$. 